\title{
Corruption, Investment and Economic Growth in WAEMU Countries
}

\author{
Ndiaye Cheikh Tidiane ${ }^{1}$ \\ ${ }^{1}$ Faculty of Economics and Management (SEG), Gaston Berger University, Saint-Louis (Senegal) \\ Correspondence: Ndiaye Cheikh Tidiane, LARES, Faculty of Economics and Management (SEG), Gaston \\ Berger University, BP.234, Saint-Louis (Senegal). Tel: 221-776-516-991/221-708-224-542. E-mail: \\ cheikh-tidiane.ndiaye@ugb.edu.sn
}

Received: February 11, 2019

Accepted: March 8, 2019

Online Published: March 13, 2019

doi:10.5539/ijef.v11n4p30

URL: https://doi.org/10.5539/ijef.v11n4p30

\begin{abstract}
The purpose of this paper is to study the relationships between corruption, public investment and economic growth in WAEMU (West Africa Economic and Monetary Union) countries during the period 2001-2014. This, by using a panel VAR (Vector Auto Regressive) model. The results stemming from this empirical study stipulate a significant link between corruption and investment, economic growth and investment, corruption and economic growth. These results also show that corruption reduces the ratio of public investment and has a negative impact on economic growth among WAEMU countries. It has more of a specific effect on investment and affects negatively through this mean countries of the area.
\end{abstract}

Keywords: public investment, economic growth, corruption and WAEMU

\section{Introduction}

Corruption, defined as the use of public goods for private purposes, has grown after independence in Africa, where the bureaucracies of African countries previously focused on good governance have gradually turned to political sovereignty and heritage (Hope et al., 2000). The many development policies developed in sub-Saharan Africa in general and in French-speaking Africa in particular have been labeled inefficient due to mismanagement of resources that are often diverted from their primary use. Contributors as well as donors of international aid are putting in place policies to force beneficiary countries to be more transparent in the investments made since they would bring growth.

According to Rostow (1960), one of the conditions for taking off the economy would be an increase in the productive investment rate from 5\% to 10\% of national income. Mijiyawa (2013) shows that economic growth in Africa depends on investment, private sector access to credit, government efficiency, exports and value added in agriculture GDP. Investment is therefore undoubtedly one of the sources of fluctuations in the growth of African countries in general of the West African Economic and Monetary Union in particular. However, it may happen that the investment does not have the expected effects on growth because of the obstacles it faces such as the corruption that makes it ineffective (Ouatarra, 2010). Thus, the concept of transparency in management methods has become much more important in recent decades.

The transparency issues are much more important in the sub-regional blocks and raise questions about economic analysis or economic assessments. Indeed, set up in 1994, the West African Economic and Monetary Union (WAEMU) has set itself the objective of, inter alia, the competitiveness of the economic activities of the member countries through market liberalization. In a classical approach, this free trade should lead to lower prices and higher domestic demand. However, the persistence of corruption can influence economic activity through an increase in production costs leading to an increase in prices (Sakar \& Hasan, 2001). This thus hinders the main objective of competitiveness in the economic activities established by WAEMU. The issue of corruption is much more prevalent today, especially in unions where countries only have the fiscal instrument as an object of economic policy. In a Keynesian approach, fiscal policy can be an instrument for boosting economic activity if the investments are made in productive economic sectors. Since corruption prevents investment from being allocated optimally, it can create distortions and negatively affect economic activity (Tanzi \& Davoodi, 1997). These are the questions that constitute the debates between economists around the three themes of corruption, public investment and growth.

The opinions of economists on the relations between corruption, investment, and economic growth are not settled. Since the first empirical work of Mauro (1995), the debate between the possible interactions between 
corruption, investment and economic growth opposes two big blocks: On the one hand there are authors who argue in favor of a negative relationship between corruption and growth through a decline in the efficiency of investment and on the other hand there are those that stipulate that corruption can have a positive effect on economic growth.

Some authors argue that corruption is an impediment to growth through various influences on public investment. Schleifer and Vishny (1993) believe that corruption has detrimental effects on economic activity through two main channels, in the first place it weakens institutions and stimulates less and less economic activity; second, it redirects resources into less productive sectors and causes distortions in the economy. According to Mauro (1995), corruption reduces public investment and thereby contributes to the decline in economic growth. Tanzi and Davoodi (1997) identify different channels through which corruption leads to a decline in economic growth: an increase in public investment but a decline in productivity, leading to a decline in economic growth.

For Leff (1964) and Huntington (1968), corruption would have a positive effect on growth. Firstly, it shortens the deadlines for public services by providing bribes to service providers. It would therefore be beneficial for countries with a heavy bureaucracy where turnaround times are long (Acemoglu \& Verdier, 1998). Secondly, it would encourage the various public service actors to work more, which would lead the agents to be productive regardless of the paperwork of the administrative services. Despite these differences of opinion, very few studies have been conducted in the WAEMU zone on the possible relations between corruption, public investment and economic growth, with empirical justifications except those of Lahna (2009) and Ouattara (2011).

Referring to the lack of literature on the union and the topicality of the debate, this article aims to complete the literature by analyzing the links between public investment and economic growth in the presence of corruption during the period 2001-2014 in the WAEMU countries. More specifically, it will be a question of seeing if the corruption has effects on the public investment and of analyzing the influence if it exists, of this investment on the economic growth of the WAEMU countries. Thus, this article is divided into two sections: the first part reviews the work on the subject and the second one presents the variables before exposing the methodology, results, and discussions.

\section{Literature Review}

Corruption has gained momentum over the last few decades. This has led several researchers to take an interest in this scourge by checking whether it constitutes an obstacle to the economic development of countries. This section presents the different theoretical and empirical work carried out for this purpose.

\subsection{Theoretical Developments on Corruption, Investment, and Economic Growth}

In the economic literature, several authors have reflected on the relationship between public investment, corruption and economic growth. As early as 1975, Rose-Ackerman examines the relationship between market structure and the incidence of corruption in the procurement process. The author analyzes different cases: the situation in which government preferences are well defined and companies compete, leading to a low risk of corruption; the case in which government preferences are "vague" where the risk of corruption becomes significant. The author finally postulates that by eliminating the competitive hypothesis and considering only the case of the bilateral monopoly, there is much more a risk of personal enrichment of the agents than a risk of corruption itself.

Corruption would be much more guided by the rent-seeking process. Economic agents, in order to increase their well-being, will take advantage of the political environment to generate rents that do not necessarily come from wealth-creating activities for the community: this would reduce the efficiency of the economy, investment and therefore the economic activity of a country (Rose Ackermann, 2006). Thus, according to Rose-Ackerman (1978), it is even difficult to limit corruption, in the case where it would be desirable in the fields where it would be economically desirable. According to Murphy, Shleifer, and Vishny (1991), the countries where qualified people are engaged in rent seeking are seeing their economic activity decline. Economic debates about the effects of corruption on economic growth, for example, support the argument that corruption, through its negative effect on investment and prices, would slow the economic growth of the countries exposed to it.

Shleifer and Vishny (1993) examine two main reasons why corruption can slow down economic growth. First, the structure of government institutions and political processes are very important determinants of the level of corruption. Second, its illegal nature leads to the creation of distortions in the economy, especially in developing countries where institutions are weak. It would ultimately have a negative impact on growth and would be very costly for the development of countries. The relations between corruption, economic growth and investment are also seen from an endogenous point of view: Mauro (1995) shows that corruption reduces not only investment 
but also economic growth through an endogenous channel: Not only the climate of institutions affects economic growth, but economic growth, too, can affect institutions and thereby corruption. Mauro asserts that in the presence of endogeneity, corruption, bureaucracy and bureaucratic inefficiency are negatively correlated with economic growth. His work is the first empirical sketch of the relationship between corruption, growth and investment, although the latter does not put together public and private investment, nor does it intrinsically release an effect of public investment on economic growth. Going in the same direction, Tanzi and Davoodi (1997) showed that corruption distorts the decision-making process related to the set of public investment projects. They also show that it has a negative effect on government revenues, public spending, the quality of public infrastructure, but it increases investment while reducing productivity. It is through these channels that corruption lowers growth. In addition to the pioneering work of Mauro, Tanzi, and Davoodi, there are still few empirical studies that have attempted to understand the relationship between corruption, public investment, and economic growth.

\subsection{Empirical Work on the Relationship between Growth, Corruption and Public Investment}

Although the literature of recent decades contains writings on the interrelationships between growth, corruption and the economy, very few authors have tried to measure the interdependencies between these three concepts, through an econometric analysis. Some empirical studies, however, have tried to understand the interdependencies between these three notions through analyzes. Ronald et al. (2000) carry out a very large review of corruption in Africa, emphasizing its very detrimental role on the economic growth of countries, the AIDS tax of democracy. However, their study focuses little on the countries of Francophone Africa (except Cameroon) and relies more on analyzes than empirical studies. It is noted that no country in the WAEMU zone has been studied by the authors who only discussed Ghana in the West African zone. Mo (2000) analyzes the impact of corruption on economic growth using data from 54 countries and an average of indicators. Regressions were performed by the authors without taking into account temporal variations.

In addition, Haque and Kneller (2007) examine the effect of public investment on growth in the presence of corruption. To do this, they use variables such as public expenditure and investment, the corruption index, the International Country Risk Guide (ICRG); they measure public investment using data from the Central Administration of Capital Expenditures for 1970-2000 for 66 countries (IMF) as well as other control variables. The model used is a 4-equation panel model: the per capita GDP growth rate, the public investment log, the private investment log, corruption and public investment. The results reveal that corruption increases the level of public investment, but lowers the return on this investment, reduces its effect on economic growth.

Lahna (2009) meanwhile, conducted a study whose objectives are to assess the elasticity of economic growth in relation to corruption in WAEMU countries and to determine the effect of corruption on growth. economic development of the WAEMU zone over the 2004-2008 period, using the growth rate of GDP as an endogenous variable representing economic growth; the investment rate, the level of corruption and the openness rate as exogenous variables. The model used is the panel model with common effects. The results show that corruption has a negative and significant effect on the growth of WAEMU countries. In the same vein, Baliamoune-Lutz and Ndikumana (2007) present a study on the analysis of the consequences of corruption on public and private investment in African countries in order to examine one of the channels through which corruption undermines growth by using the generalized method of moments (GMM) estimator developed by Arellano and Bond (Arellano \& Bond, 1991). Empirical results indicate that corruption affects economic growth directly and through its impact on investment. They then show that corruption has a negative and significant effect on domestic investment and affects public and private investment differently. Finally, corruption has a positive effect on public investment and negative on private investment.

In 2011, Ouattara analyzes the impact of corruption on public and private investments in Côte d'Ivoire and assesses their effects on economic growth. It uses as variables the share of public investment in the GDP and Transparency International's Corruption Perception Index, the rate of economic growth, the degree of openness, the share of private investment in GDP, the rate of inflation and external debt as a ratio of GDP. Macroeconomic data, covering the period from 1998 to 2009, are from the World Bank's World Development Indicators (WDI) database. The model used is the simultaneous equation model. The results show that corruption is a factor of overestimation of the amount of investment in Côte d'Ivoire, that these have bad effects on economic growth and that public investments have a crowding-out effect on private investment. Zouhaier (2012) studies the effect of corruption on investment and economic growth in a group of 11 Middle East North Africa (MENA) countries during the period 2000-2009, using a dynamic panel data model. It shows that there is a significant link between corruption and investment on the one hand and corruption and economic growth on the other and a positive effect of political institutions on economic growth. 


\section{Econometric Analyzes and Discussions}

This section presents the variables included in the model and the data sources, and the methodology adopted as well as the results of the estimation and the discussions are presented.

\subsection{Choice and Justification of Variables}

Corruption is a phenomenon that covers several dimensions; this multi-dimensionality makes the notion of corruption difficult to measure and very subjective. Andrew Williams (2005) reviews the various indicators used in the area of governance, from pioneering work to recent composite indexes such as the Corruption Perception Index (CPI) or the International Country Risk Guide (ICRG). These are the main sources that are used in the literature, because they have a relatively long time period and a very large country coverage, compared to other indicators of measuring corruption such as CPIA (Country Policy and Institutional Assessment) and BI (Business International) which cover very short periods of time and do not have much data. Corruption is measured at the level of the CPI or the ICRG through a set of sub-indicators resulting from different opinion polls conducted or expert opinion that all relate to the perception of corruption in a country. The International Country Risk Guide (ICRG) is a set of governance indicators covering nearly 140 countries on various aspects of governance, including corruption. Its main disadvantage is that it comes from expert advice and is more focused on foreign investors than on domestic agents. The IPC is a composite indicator of Transparency International created in 1995 that groups sub-indicators from different surveys in the countries represented. This index has the advantage of not being obtained from subjective methods resulting from the experts' statements, but also from being drawn from a survey on the perception of corruption by domestic agents. Its main disadvantage is the multiplicity of data sources that enter into its construction. However, adequate standardization can solve this problem. This is the index that we will retain in our analyzes.

Public investment is public expenditure as a whole to improve or increase productive capacity. In national accounts, investment is measured by the gross fixed capital formation which relates to the acquisition value of fixed tangible or intangible assets. However, it is measured in the budget of WAEMU member states through a broader vision, the capital expenditure which includes capital expenditures and capital transfers. It is this last notion that we will retain as the definition of public investment. We will consider the ratio of capital expenditure to GDP as a variable measuring public investment in our analysis. The investment is therefore measured in terms of the government's investment rate.

Economic growth is defined as the increase in the quantity of goods and services produced in a given country (GDP) over a relatively short or long period. It will be measured through the growth rate of real GDP. The endogenous characteristics of growth and investment are an integral part of economic theory (Arrow, 1960; Lucas, 1988; Romer, 1986). Growth also depends on several factors, including export, the opening of the country and the prices measured by the rate of inflation, the fiscal policies of the country.

The endogenous nature of the investment, growth and corruption variables mainly motivates the choice of modeling methods to understand the interrelations between growth, investment and corruption. We assume in our study corruption as an endogenous variable. The relations of endogeneity between growth and corruption are debated in the economic literature. While the negative effects of corruption on growth have been highlighted by several authors, the effects of growth on corruption are not clear-cut. Indeed, since Mauro insisted on the endogenous nature of the relationship between growth and institution, some authors have postulated that growth would reduce corruption, on the basis that corruption prevails much more in poor countries than in rich ones (Bai and al., 2013). Corruption, as measured by the Corruption Perception Index, will be considered as an endogenous variable, as well as other factors that explain growth as control variables.

\subsection{Data and Stylized Facts}

The studies were carried out on a panel constituted by the WAEMU countries. The data used are annual and cover the period from 2001 to 2014. The choice of this period is due to the lack of data from Transparency International's Corruption Perception Index (CPI), first published in 1995 with the first consideration of two WAEMU countries in 1998 (Senegal, Côte d'Ivoire) and three countries in 1999.

Most of the data used for this work comes from the BCEAO database. This is the real GDP growth rate used as an indicator of economic growth, capital expenditures to measure public investment, customs taxes, public debt, export, import and inflation that are used as variables. control.

The data on corruption come from the database "Transparency International". The Corruption Perception Index (CPI) is a global indicator that ranks countries by the degree to which corruption is perceived among public officials and politicians. This index varies from 0 to 10 . The score of 0 is attributed to countries with a high level 
of corruption and 10 to countries with a low level. A summary analysis of some of these variables is needed to identify the phenomenon we want to study.

The growth rates of the WAEMU countries are changing erratically over the period 2001-2014. Public investment has increased for all the states of the Union. It should be noted that after the presidential election of November 2010, Côte d'Ivoire faced a political crisis and an armed conflict for several months which ended in April 2011. This crisis, added to the drought of Sahelian countries had an impact on the rate of growth and investment in all countries in the zone in 2011, and particularly in Côte d'Ivoire, where the growth rate of $4.38 \%$ and an increase of public investment of $12.6 \%$. The new government has launched an ambitious recovery focused on investment. This explains the change observed in 2012 when the growth rate of Côte d'Ivoire rose to 10.7\%. During the study period, countries such as Benin, Burkina Faso and Mali did not record a negative growth rate.

The evolution of the CPI from 2001 to 2014 shows that corruption is present in the WAEMU area. The analysis of this evolution makes it possible to conclude that over the period, the most corrupt countries of the Union with regard to the ranking of Transparency International are Guinea-Bissau with an average value of the index 2.1, followed by the Côte d'Ivoire and Togo with values of 2.3 and 2.6 respectively. This situation may be due to the political instability of Côte d'Ivoire over the period of the study and the persistent influence of drug traffickers in Guinea. It is also noted that in the area the least corrupt countries are Burkina which has an average score of 3.38, then Senegal and Benin with scores of 3.21 and 3.1 respectively.

\subsection{Estimation Methodology}

The methodology adopted to analyze the different inter-actions between corruption, investment and growth is the VAR modeling in panel. Indeed, the endogenous characteristics of the investment and growth variables as well as openness variables such as export, a determinant of growth, led us to consider them a priori as endogenous variables before proceeding to the modeling of inter-relationships.

More generally, the model is in the form of a VAR p with specific effects in the following form:

$$
Z_{i t}=Z_{i t-1} A_{1}+Z_{i t-2} A_{2}+\cdots+Z_{i t-p} A_{p}+X_{i t} B+u_{i}+\varepsilon_{i t}
$$

$i \in\{1, \ldots, 8\}, t \in\{1 \ldots 13\}$ whither $Z_{i t}$ is the vector of variables (Growth, Investment, Export) and $X_{\text {it }}$ the vector of exogenous variables (Inflation, Corruption Perception Index), $u_{i}$ and $\varepsilon_{i t}$ are respectively the components of specific and idiosyncratic errors. The parameters to be estimated are the matrices $A_{i}$ and $B$ under the following conditions on errors:

$\mathrm{E}\left(\varepsilon^{\prime}{ }_{\text {it }} \varepsilon_{\text {is }}\right)=0$ For everything $t>\mathrm{s}$

$$
E\left(\varepsilon_{i t}\right)=0
$$

$\mathrm{E}\left(\varepsilon^{\prime}{ }_{\text {it }} \varepsilon_{\text {is }}\right)=\Omega$ whither $\Omega$ is the covariance variance matrix of the errors.

There are different methods for estimating previous equations, with or without fixed effects, the simplest being to use ordinary least squares equation equation regressions. This leads to biased estimators as Nickell (1981) has shown. With the emergence of the GMM (Generalized Method of Moments) estimation method, under the assumption that the errors are non-autocorrelated, Anderson and Hsiao (1982) proposed using delayed variables as instrumental variables for the variables. level by differentiation. However, Arellano and Bover (1995) propose the use of a transformation of variables based on orthogonal deviations, which allows for more convergent estimators. Although equation-by-equation estimation provides consistent results, the equation model provides more efficient estimators (Holtz, Newey, \& Rosen, 1988). The model used in our analysis for estimating coefficients is based on the orthogonal deviation transformation of Arellano and Bover using the estimated GMM method in a system.

\section{The choice of optimal lag and stationary tests in panel}

The choice of the optimal lag of the VAR model is based on the examination of information criteria such as AIC, BIC or HQIC. It is the examination of these criteria that has guided the choice of the number of lag to be retained in the estimates that we have made. It should also be noted that we coupled it with a parsimony criterion, since the number of data available only covered a period of 13 years.

Table 1. Choosing the optimal lag for VAR (model 1)

\begin{tabular}{lcccccc}
\hline lag & CD & J & J pvalue & MBIC & MAIC & MQIC \\
\hline 1 & .5487 & 24.336 & .612 & -87.953 & -29.664 & -52.627 \\
2 & .527 & 13.396 & .767 & -61.463 & -22.603 & -37.912 \\
3 & .674 & 4.783 & .853 & -32.647 & -13.217 & -20.871 \\
\hline
\end{tabular}

Source: Author's calculation. 
The choice of the panel VAR model is based on the assumptions of stationary of the variables that enter into the model, although GMM estimation does not require total stationary of the variables. The stationary tests of Breitung, Im Pesaran and Shin, Levin Lu Chu and Hadri were performed on all the variables that go into the composition of the model, in order to ensure the correct specification of the chosen VAR model. The results of the tests are shown in table 2.

Table 2. Stationary of variables: table of p-values

\begin{tabular}{lcccc}
\hline & LLC & Hadri & Breitung & IPS \\
\hline Growth & $0,0003^{*}$ & $0,2784^{*}$ & $0,0000^{*}$ & $0,0000^{*}$ \\
Investment rate & $0,0338^{*}$ & $0,2000^{*}$ & 0,9581 & 0,7693 \\
Corruption & $0,0184^{*}$ & 0,0000 & 0,4635 & 0,6067 \\
\hline
\end{tabular}

Source: Author's calculation.

\subsection{Results and Discussions}

We recall that the model has as endogenous variables the growth of real GDP, the investment measured by the share of capital expenditure in the GDP and Transparency International's corruption index (CPI). The results of the stationary tests carried out on the various variables are summarized in the appendices. The model is estimated on a set of 64 observations ( 8 countries and 13 temporal data). Since the corruption index is counted for 10 for a low level of corruption and 0 for a high level of corruption, we multiplied the variable by -1 , to facilitate interpretations. So, according to our scale, the lower the index, the less corrupt a country is.

Table 3. Results of the estimated VAR model on the data

\begin{tabular}{lcccccc}
\hline & Coef & Std, Err & Z & P>Z & {$[95 \%$ Conf } & Intervalle] \\
\hline GROWTH & & & & & & \\
\hline Delayed Growth & $-0,149$ & 0,117 & $-1,280$ & 0,201 & $-0,377$ & 0,079 \\
Investment rate delayed & $-0,958$ & 0,209 & $-4,590$ & 0,000 & $-1,367$ & $-0,549$ \\
Cpi delayed & $-0,471$ & 0,179 & $-2,620$ & 0,009 & $-0,822$ & $-0,119$ \\
Exports & 0,703 & 0,276 & 2,550 & 0,011 & 0,163 & 1,243 \\
Inflation & $-0,080$ & 0,124 & $-0,640$ & 0,520 & $-0,324$ & 0,164 \\
Opening rate & $-0,656$ & 0,194 & $-3,380$ & 0,001 & $-1,037$ & $-0,276$ \\
Customs rate & $-14,122$ & 2,698 & $-5,230$ & 0,000 & $-19,410$ & $-8,834$ \\
Outstanding debt & $-0,016$ & 0,027 & $-0,600$ & 0,546 & $-0,070$ & 0,037 \\
\hline RATE OF INVES TMENT & & & & & & \\
\hline Delayed Growth & $-0,010$ & 0,042 & $-0,240$ & 0,809 & $-0,092$ & 0,071 \\
Investment rate delayed & 0,712 & 0,084 & 8,500 & 0,000 & 0,548 & 0,876 \\
Cpi delay ed & $-0,412$ & 0,089 & $-4,640$ & 0,000 & $-0,586$ & $-0,238$ \\
Exports & 0,215 & 0,100 & 2,150 & 0,031 & 0,019 & 0,410 \\
Inflation & $-0,089$ & 0,052 & $-1,700$ & 0,088 & $-0,190$ & 0,013 \\
Opening rate & $-0,212$ & 0,074 & $-2,850$ & 0,004 & $-0,357$ & $-0,066$ \\
Customs rate & 0,320 & 1,253 & 0,260 & 0,799 & $-2,136$ & 2,776 \\
Outstanding debt & 0,013 & 0,011 & 1,220 & 0,222 & $-0,008$ & 0,034 \\
\hline CPI & & & & & & \\
\hline Delayed Growth & 0,160 & 0,040 & 4,020 & 0,000 & 0,082 & 0,238 \\
Investment rate delayed & 0,141 & 0,062 & 2,280 & 0,023 & 0,020 & 0,263 \\
Cpi delayed & 0,964 & 0,070 & 13,760 & 0,000 & 0,827 & 1,102 \\
Exports & $-0,281$ & 0,058 & $-4,810$ & 0,000 & $-0,395$ & $-0,166$ \\
Inflation & 0,051 & 0,035 & 1,470 & 0,142 & $-0,017$ & 0,119 \\
Opening rate & 0,164 & 0,043 & 3,790 & 0,000 & 0,079 & 0,248 \\
Customs rate & 4,718 & 0,660 & 7,150 & 0,000 & 3,424 & 6,011 \\
Outstanding debt & 0,025 & 0,003 & 8,910 & 0,000 & 0,019 & 0,030 \\
\hline & & & & & &
\end{tabular}

Source: Author's calculation.

The analysis in Table 3 allows us to conclude that the growth rate depends on public investment in the previous period, corruption in period t-1, exports, the degree of trade openness and the customs rate. These variables are indeed significant at the $5 \%$ level. On the other hand, variables such as the growth rate in the previous period, inflation, public debt are not significant at the same threshold of 5\%. As for public investment, it depends on investment in the previous period, corruption in the previous period, and the degree of trade openness. Variables such as the growth rate in the previous period, exports, inflation, the customs rate and the public debt are not significant at the $5 \%$ level. 
All things otherwise being equal, the analysis of the results shows that an increase of one unit of the investment ratio in the previous period leads to a slowdown in growth of $0.96 \%$. The expansionist policies pursued by the countries are indeed often accompanied by a period of recession, before a resumption of growth in the following periods, according to the Keynesian approach. Similarly, an increase of one unit of the corruption index, the customs rate, the degree of openness leads to a slowdown in growth of $0.47 ; 14.12$ and 0.66 respectively. The presence of corruption in the WAEMU countries is therefore a source of slowing economic growth in these countries. Since the WAEMU countries are importing countries with a deficit trade balance (with the exception of Côte d'Ivoire, which has surpluses), it is therefore normal for the degree of openness (which is more borne by imports) has a negative impact on economic growth. On the other hand, always assuming everything else equal, a one-unit increase in exports leads to $0.7 \%$ growth recovery.

Speaking of the ratio of public investment to GDP, the results show that an increase of one unit of this ratio to the previous period and exports, leads to an increase in the ratio to the present period of 0.7 and 0.4 respectively. On the other hand, an increase of one unit of the corruption index and the degree of openness leads to a decrease in the investment ratio of 0.41 and 0.21 respectively. Corruption thus has a negative effect on the investment rate of the countries of the zone. The results are consistent with those conducted by Ouattara (2001) for Côte d'Ivoire and Lahna for WAEMU countries.

Table 4 shows the results of the estimates made by introducing the cross variable investment $*$ corruption (cpi). The purpose of this variable is to examine, where appropriate, the cross-over effect of investment and corruption on economic growth, or the behavior of other variables in the presence of the cross-effect. In the presence of the intersection between public investment rate and corruption, the corruption index is no longer significant at the 5\% growth threshold as well as the investment-corruption cross variable. This suggests a not direct effect of corruption on the economic growth of the WAEMU countries, but rather an indirect effect, through the channel of public investment. The public investment rate achieved in period $\mathrm{t}-1$ is, as it was previously, negatively related to growth. In general, very few exogenous variables are significant except for the debt-to-GDP ratio which, when high, causes a slowdown in economic growth in the zone countries according to economic theory.

Table 4. Results of estimates with cross effects

\begin{tabular}{lcccccc}
\hline & Coef & Std, Err & $\mathrm{z}$ & $\mathrm{P}>\mathrm{Z}$ & {$[95 \%$ Conf } & Intervalle] \\
\hline GROWTH & & & & & & \\
\hline Delayed Growth & 0,010 & 0,150 & 0,060 & 0,950 & $-0,280$ & 0,300 \\
Investment rate delayed & $-0,900$ & 0,180 & $-4,950$ & 0,000 & $-1,260$ & $-0,540$ \\
Cpi delayed & $-0,460$ & 0,310 & $-1,480$ & 0,140 & $-1,080$ & 0,150 \\
Cross-corruption-investment effect & $-0,010$ & 0,030 & $-0,220$ & 0,830 & $-0,070$ & 0,050 \\
Inflation & $-0,130$ & 0,110 & $-1,180$ & 0,240 & $-0,360$ & 0,090 \\
Exports & 0,410 & 0,330 & 1,240 & 0,210 & $-0,240$ & 1,070 \\
Opening rate & $-0,470$ & 0,260 & $-1,830$ & 0,070 & $-0,980$ & 0,030 \\
Customs rate & $-14,750$ & 2,410 & $-6,120$ & 0,000 & $-19,480$ & $-10,030$ \\
Outstanding debt & $-0,050$ & 0,020 & $-2,290$ & 0,020 & $-0,090$ & $-0,010$ \\
\hline RATE OF INVESTMENT & & & & & & \\
\hline Delayed Growth & 0,120 & 0,060 & 2,060 & 0,040 & 0,010 & 0,230 \\
Investment rate delayed & 0,150 & 0,070 & 2,030 & 0,040 & 0,010 & 0,300 \\
Cpi delayed & 0,840 & 0,210 & 4,080 & 0,000 & 0,440 & 1,240 \\
Cross-corruption-investment effect & $-0,100$ & 0,010 & $-8,480$ & 0,000 & $-0,130$ & $-0,080$ \\
Inflation & $-0,110$ & 0,050 & $-2,230$ & 0,030 & $-0,210$ & $-0,010$ \\
Exports & $-0,100$ & 0,100 & $-0,940$ & 0,350 & $-0,300$ & 0,100 \\
Opening rate & 0,000 & 0,080 & $-0,050$ & 0,960 & $-0,160$ & 0,150 \\
Customs rate & $-2,260$ & 1,060 & $-2,130$ & 0,030 & $-4,340$ & $-0,180$ \\
Outstanding debt & 0,000 & 0,000 & 0,510 & 0,610 & $-0,010$ & 0,010 \\
\hline CPI & & & & & & \\
\hline Delayed Growth & 0,120 & 0,070 & 1,730 & 0,080 & $-0,020$ & 0,250 \\
Investment rate delayed & 0,460 & 0,050 & 9,720 & 0,000 & 0,370 & 0,560 \\
Cpi delayed & 0,440 & 0,200 & 2,220 & 0,030 & 0,050 & 0,830 \\
Cross-corruption-investment effect & 0,040 & 0,010 & 3,160 & 0,000 & 0,020 & 0,070 \\
Inflation & 0,060 & 0,050 & 1,040 & 0,300 & $-0,050$ & 0,160 \\
Exports & $-0,060$ & 0,090 & $-0,700$ & 0,480 & $-0,240$ & 0,110 \\
Opening rate & 0,000 & 0,070 & $-0,040$ & 0,970 & $-0,130$ & 0,130 \\
Customs rate & 5,990 & 0,930 & 6,420 & 0,000 & 4,160 & 7,820 \\
Outstanding debt & 0,040 & 0,010 & 4,690 & 0,000 & 0,020 & 0,060 \\
\hline & & & & & & \\
& & & & & & \\
& & &
\end{tabular}

Source: Author's calculation.

The isolated effect of corruption on the share of investment in GDP is positive. This suggests that in the WAEMU countries, an increase in corruption taken in isolation, is accompanied by an increase in public spending. The effect of the rate of duty and the debt on corruption and when controlling for the common 
corruption-investment effect is positive. Union countries with high tariffs and high debt-to-GDP ratios have high levels of corruption. Indeed, WAEMU countries finance their public investment with funds raised both on the capital market and from financial institutions. The results suggest that the higher the amounts raised, the higher the corruption in the country.

\section{Conclusion}

At the end of this study, which aimed to study the links between public investment, economic growth and corruption during the period 2001-2014 in the WAEMU countries, the results of estimates allow us to confirm that there are interdependencies between these three concepts. The analytical approach used to analyze these different relationships is VAR panel modeling. The results show that corruption reduces public investment and consequently negatively impacts economic growth.

Corruption is therefore a source of slowdown in the growth of WAEMU countries that aspire to economic emergence. This raises questions about the legal measures for establishing an independent body to be in line with the recommendations of the United Nations Convention against Corruption (UNCAC), which calls on States Parties to create one or more independent anti-corruption agencies (Article 6). Similarly, in terms of the development and credibility of economic policies, the WAEMU authorities must put in place clauses to compel member countries to promote transparency and probity in the management of public and private affairs.

\section{References}

Abrigo, M. R, Love, I. et al. (2015). Estimation of panel vector autoregression in Stata: A package of programs. Retrieved from http://paneldataconference2015.ceu. hu/Program/Michael-Abrigo.Pdf

Acemoglu, D., \& Verdier, T. (1998). Property rights, corruption and the allocation of talent: A general equilibrium approach. The Economic Journal, 108, 1381-1403. https://doi.org/10.1111/1468-0297.00347

Ackerman, S. R. (1978). Corruption: A study in political economy. New York : Academic Press.

Aidt, T. S. (2003). Economic analysis of corruption: A survey. The Economic Journal, 113, F632-F652. https://doi.org/10.1046/j.0013-0133.2003.00171.x

Alfredo, M. P. (2001). On the effects of public investment on private investment: What crowds in what? Public Finance Review, 29, 3-25. https://doi.org/10.1177/109114210102900101

Arellano, M., \& Bover, O. (1995). Another look at the instrumental variable estimation of error-components models. Journal of Econometrics, 68, 29-51. https://doi.org/10.1016/0304-4076(94)01642-D

Bai, J., Jayachandran, S., Malesky, E. J., \& Olken, B. A. (2013). Does economic growth reduce corruption? Theory and evidence from Vietnam. National Bureau of Economic Research. https://doi.org/10.3386/w19483

Baliamoune-Lutz, M., \& Ndikumana, L. (2007). Corruption et croissance dans les pays africains: Le canal de l'investissement. Actes de la Conférence 2007.

Barro, R. J. (1988). Government spending in a simple model of endogenous growth.

Burguet, R., \& Che, Y. K. (2004). Competitive procurement with corruption. Journal of Economics, 50-68. https://editorialexp... i-bin/rje_online.cgi

Canova, F., \& Ciccarelli, M. (2013). Panel Vector Autoregressive Models: A Survey. VAR Models in Macroeconomics-New Developments and Applications: Essays in Honor of Christopher A. Sims (Advances in Econometrics, Volume 32, pp. 205-246). Emerald Group Publishing Limited. https://doi.org/10.1108/S0731-9053(2013)0000031006

Celentani, M., \& Ganuza, J. J. (2002). Corruption and competition in procurement. European Economic Review, 46, 1273-1303. https://doi.org/10.1016/S0014-2921(01)00147-7

Chow, G. C. (1960). Tests of equality between sets of coefficients in two linear regressions. Econometrica: Journal of the Econometric Society, 591-605. https://doi.org/10.2307/1910133

Collier, P. (2000). How to reduce corruption. African Development Review, 12, 191-205. https://doi.org/10.1111/1467-8268.00022

Dusek, L., Ortmann, A., \& Lizal, L. (2005). Understanding corruption and corruptibility through experiments: A primer. Prague Economic Papers, 14, 147-162. https://doi.org/10.18267/j.pep.259

Fedeli, S., \& Forte, F. (2003). Public Co-Financing of Private Sector's Investments: Subsidiarity and Corruption. Public Choice, 116, 109-145. https://doi.org/10.1023/A:1024269330619 
Gyimah-Brempong, K. (2002). Corruption, economic growth, and income inequality in Africa. Economics of Governance, 3, 183-209. https://doi.org/10.1007/s101010200045

Habib, M., \& Zurawicki, L. (2002). Corruption and foreign direct investment. Journal of International Business Studies, 33, 291-307. https://doi.org/10.1057/palgrave.jibs.8491017

Haque, M. E., Kneller, R. et al. (2008). Public investment and growth: The role of corruption. Centre for Growth and Business Cycle Research discussion paper series, 98.

Holtz-Eakin, D., Newey, W., \& Rosen, H. S. (1988). Estimating vector autoregressions with panel data. Econometrica: Journal of the Econometric Society, 1371-1395. Retrieved from http://links.jstor.org/sici?sici=0012-9682\%2819881... O\%3B2-V\&origin=repec full text (application/pdf)

Hope, K., \& Chikulo, B. (2000). Corruption and development in Africa: Lessons from Country Case Studies. Palgrave Macmillan UK.

IMF. (2002). The persistence of corruption and slow economic growth. IMF Working Papers 02/213, International Monetary Fund. Retrieved from https://ssrn.com/abstract=880888

Jain, A. K. (2001). Corruption: A review. Journal of Economic Surveys, 15, 71-121. https://doi.org/10.1111/1467-6419.00133

Knack, S., \& Keefer, P. (1997). Does social capital have an economic payoff ? A cross-country investigation. The Quarterly Journal of Economics, 1251-1288. https://doi.org/10.1162/003355300555475

Larrain, B., Tavares, J. et al. (2004). Does foreign direct investment decrease corruption? Cuadernos de Economia, 41, 199-215. https://doi.org/10.4067/S0717-68212004012300003

Martin, A. (2004). Transparency International Corruption Perceptions Index 2003. Oil, Gas \& Energy Law Journal, (OGEL)2.

Mauro, P. (1995). Corruption and growth. The Quarterly Journal of Economics, 681-712. https://doi.org/10.2307/2946696

Mo, P. H. (2001). Corruption and economic growth. Journal of Comparative Economics, 29, 66-79. https://doi.org/10.1006/jcec.2000.1703

Paolo, M. (1998). Corruption and the composition of government expenditure. Journal of Public Economics, 69, 263-279. https://doi.org/10.1016/S0047-2727(98)00025-5

Pereira, A. M. (2000). Is all public capital created equal? Review of Economics and Statistics, 82, 513-518. https://doi.org/10.1162/rest.2000.82.3.513

Pereira, A. M., \& Frutos, R. F. (1999). Public capital accumulation and private sector performance. Journal of Urban Economics, 46, 300-322. https://doi.org/10.1006/juec.1998.2124

Podrecca, E., \& Carmeci, G. (2001). Fixed investment and economic growth: New results on causality. Applied Economics, 33, 177-182. https://doi.org/10.1080/00036840122890

Rose-Ackerman, S. (1975). The economics of corruption. Journal of Public Economics, 4, 187-203. https://doi.org/10.1016/0047-2727(75)90017-1

Rose-Ackerman, S., \& Kawata, J. (2006). Political corruption and reform in democracies: Theoretical perspectives. Comparing Political Corruption, 45-62. https://doi.org/10.1017/CBO9781139962933

Saba, A. J. (2010). Silent and lethal: how quiet corruption undermines Africa's development efforts. Africa Development Indicators, Washington, DC: World Bank Group. Retrieved from http://documents.worldbank.org/curated/en/316051468009960660/Silent-and-lethal-how-quiet-corruption-u ndermines-Africas-development-efforts

Salami, M. (2009). Analyse des Effets de la corruption sur la croissance des pays de l'UEMOA: Une étude sur la période 2004-2008. Thèse de doctorat.

Sarkar, H., \& Hasan, M. A. (2001). Impact of corruption on the efficiency of investment: Evidence from a cross-country analysis. Asia-Pacific Development Journal, 8, 111-116.

Shibata, H., \& Ihori, T. (1998). The welfare state, public investment and growth. Springer. https://doi.org/10.1007/978-4-431-67939-4

Shleifer, A., \& Vishny, R. W. (1993). Corruption. The Quarterly Journal of Economics, 108(3), 599-617. https://doi.org/10.2307/2118402 
Soumaila, I. (2014). Efficacité des investissements dans l'UEMOA. Document d'étude et de Recherche, BCEAO, $N^{\circ} D E R / 14 / 02$, p. 45.

Svensson, J. (2005). Eight questions about corruption. The Journal of Economic Perspectives, 19, 19-42. https://doi.org/10.1257/089533005774357860

Swaleheen, M. (2007). Corruption and investment choices: A panel data study. International Review for Social Sciences, 60(4), 601-616. https://doi.org/10.1111/j.1467-6435.2007.00387.x

Swaleheen, M. (2011). Economic growth with endogenous corruption: An empirical study. Public Choice, 146(1-2), 23-41. https://doi.org/10.1007/s11127-009-9581-1

Tachiwou, A. M. (2014). Corruption and Economic Development in West African Economic and Monetary Union (UEMOA). Journal of US-China Public Administration, 11, 522-531.

Tanzi, V., \& Davoodi, H. (1997). Corruption, public investment, and growth. Working Paper of International Monetary Fund, WP/97/139, p. 23. https://doi.org/10.5089/9781451929515.001

Toyoda, T., \& Ohtani, K. (1986). Testing equality between sets of coefficients after a preliminary test for equality of disturbance variances in two linear regressions. Journal of Econometrics, 31(1), 67-80. https://doi.org/10.1016/0304-4076(86)90056-4

Treisman, D. (2000). The causes of corruption: A cross-national study. Journal of Public Economics, 76(3), 399-457. https://doi.org/10.1016/S0047-2727(99)00092-4

Williams, A., \& Siddique, A. (2008). The use (and abuse) of governance indicators in economics: A review. Economics of Governance, 9(2), 131-175. https://doi.org/10.1007/s10101-006-0025-9

Williamson, O. E. (2000). The new institutional economics: Taking stock, looking ahead. Journal of Economic Literature, 38(3), 595-613. https://doi.org/10.1257/jel.38.3.595

Zouhaier, H., \& Kefi, M. K. (2012). Corruption, investissement et croissance économique. Unité de Recherche: Entreprise Environnement Economie, CERI/PRISM Sorbonne-Paris-France, 19.

\section{Copyrights}

Copyright for this article is retained by the author(s), with first publication rights granted to the journal.

This is an open-access article distributed under the terms and conditions of the Creative Commons Attribution license (http://creativecommons.org/licenses/by/4.0/). 